УДК 811.112 .2

DOI: https://doi.org/10.18524/2307-4604.2017.2(39).118629

Vovchanska S.I.

Ph.D, Assistant Professor, Ternopil National Economic University

\title{
PROFESSIONAL GLOTTODIDACTICS AS A NEW ASPECT OF LSP STUDY
}

In recent years the research of LSP (Languages for Special Purposes) has acquired special relevance because of formation of professional lexicon systems in different branches. Whatever happens to people, whatever they create within centuries to some extent effects the language in terms of forming the peculiarities of the national linguistic world-image. The modern era is marked by rapid, evident development of new scientific and professional branches which have a considerable influence on the standard of social and cultural life of society. In view of these processes and phenomena, not only linguistic researches of LSP play more and more relevant role, but also the glottodidactic direction of LSP studies.

Keywords: glottodidactics, Languages for Special Purposes (LSP), LSP study.

Вовчанська C.І. Фахова глоттодидактика як новий аспект навчання фахових мов. Дана стаття експлікує один із релевантних напрямків у дослідженні фрахових мов, оскільки сучасна епоха відзначається стрімким, евідентним розвитком нових наукових і професійних галузей, які здійснюють прегнантний вплив на рівень соціального та культурного життя суспільства. 3 огляду на ці процеси і явища все більш релевантного значення відіграють не лише лінгвістичні дослідження фрахових мов, а й глоттодидактичний напрям навчання фрахових мов.

Ключові слова: фрахова мова, глоттодидактика, термінологія.

Вовчанская С.И. Профессиональная глоттодидактика как новый аспект обучения профессиональных языков. Данная статья эксплицирует одно из релевантных направлений в исследовании профессиональных языков, поскольку современная эпоха отмечается стремительным, евидентним развитием новых научных и профессиональны отраслей, которые осуществляют прегнантное влияние на уровень социальной и культурной жизни общества. Учитывая эти процессы и явления все более релевантное значение играют не только лингвистические исследования профессиональных языков, но и глоттодидактичное направление учебы профессиональных языков.

Ключевые слова: профрессиональный язык, глоттодидактика, терминология.

\section{INTRODUCTION}

As Sambor Grucza [1] states in his work «History of linguistics of the professional text» the glottodidactic aspect of LSP researches was formed in Poland in the 70-80-ies of the XX century. The didactics of specialized languages can trace its origin back to the period of so-called lexical and grammatical LSP researches, the time of domination of the structural theory which defined a specialized language (as well as language in general) as a system of language signs and syntax rules. During the following years the works of researchers were concentrated on the issues of specialized texts (the so-called textological period or the period of the development of «text linguistics of specialized languages») [2], though problems of terminology studies remained to be a target point of fur- 
ther scholar research. Within this period (the 80 -s of the XX century), the tasks of didactics of LSP were defined as a tendency to master the basic terminology and the most important language constructions in the sphere of professional language, as well as to develop competences of processing and understanding professional texts in relation with lexical competence.

\section{ASPECTS OF LSP RESEARCHES \\ (in the English, German, Polish and Ukrainian languages)}

The selection of languages for visualization of a comparative pattern of LSP research, in particular English, German, Polish and Ukrainian, is based on the following principles: the comparison of language potential of two language groups, namely Germanic (the English and German languages) and Slavic (the Polish and Ukrainian languages), and the assistance of cross-language and cross-cultural interaction at the level of professional communication and the professional text.

Generalization of the received data has made it possible to compile the table that displays the following investigated aspects of LSP with regard to four specific languages.

Table 1

Systematization of investigated aspects of LSP

\begin{tabular}{|l|c|c|c|}
\hline \multicolumn{3}{|c|}{ INVESTIGATION LANGUAGES } \\
\hline \multicolumn{2}{|c|}{ LSP (INVESTIGATION ASPECTS) } \\
\hline $\begin{array}{c}\text { RAILROAD } \\
\text { - Semantic compression in } \\
\text { word formation; } \\
\text { - Language History }\end{array}$ & - & - \\
\hline $\begin{array}{l}\text { SEAWORTHINESS } \\
\text { - Types of professional texts; } \\
\text { - Composition of professional } \\
\text { lexicon }\end{array}$ & - & - \\
\hline $\begin{array}{l}\text { TELECOMMUNICATION } \\
\text { - Syntactic phenomena }\end{array}$ & - & - \\
\hline $\begin{array}{l}\text { MATHEMATICIAN } \\
\text { - The Phenomenon of } \\
\text { specifications; } \\
\text { - The Word order; } \\
- \text { The spelling Method; } \\
\text { - Representation of } \\
\text { professionalism in texts }\end{array}$ & - & - & \\
\hline $\begin{array}{c}\text { PHYSICS } \\
\text { - Terminology }\end{array}$ & & & \\
\hline
\end{tabular}




\begin{tabular}{|c|c|c|c|}
\hline $\begin{array}{l}\text { CHEMISTRY } \\
\text { - The diachronic aspect; } \\
\text { - Etymological investigations } \\
\text { of chemical designations; } \\
\text { - the Research of language } \\
\text { of symbols and signs; } \\
\text { - Syntax; } \\
\text { - Professional glottodidactics }\end{array}$ & $\begin{array}{l}\quad \text { CHEMISTRY } \\
\text { - Professional } \\
\text { lexicon; } \\
\text { - Syntax }\end{array}$ & - & - \\
\hline - Syntax & - & - & - \\
\hline $\begin{array}{r}\text { PHARMACY } \\
\text { - Professional lexicon }\end{array}$ & - & - & - \\
\hline \begin{tabular}{l}
\multicolumn{1}{c|}{ MEDICINE } \\
- Lexical and semantic \\
structures; \\
- Syntax
\end{tabular} & - & - & - \\
\hline $\begin{array}{l}\text { LAW AND MANAGEMENT } \\
\text { - Communicative aspect; } \\
\text { - Syntax }\end{array}$ & - & \begin{tabular}{l}
\multicolumn{1}{c|}{ LAW } \\
- The glottodidactic \\
aspect; \\
- Polilect of law \\
language \\
- The opportunities \\
and restrictions \\
of teaching the \\
translation of \\
professional texts; \\
- Distribution \\
of grammatical \\
categories of a \\
verb
\end{tabular} & $\begin{array}{l}\text { LAW } \\
\text { - Types of } \\
\text { professional } \\
\text { texts }\end{array}$ \\
\hline \begin{tabular}{l}
\multicolumn{1}{c}{ MUSIC } \\
- Terminology; \\
- Musical and scientific \\
means of the image; \\
- Type of text \\
(musical criticism)
\end{tabular} & - & - & - \\
\hline
\end{tabular}


VOVCHANSKA S.I. PROFESSIONAL GLOTTODIDACTICS...

\begin{tabular}{|c|c|c|c|}
\hline $\begin{array}{l}\quad \text { LITERATURE } \\
\text { - Terminology; } \\
\text { - Existence of rhetorical } \\
\text { means in literary } \\
\text { professional texts }\end{array}$ & \begin{tabular}{l}
\multicolumn{1}{|c}{ LITERATURE } \\
- Problems \\
of a literary \\
metalanguage; \\
- Syntactic statistic \\
analysis; \\
- Invariant signs \\
of a literary and \\
critical essay and a \\
review
\end{tabular} & - & - \\
\hline $\begin{array}{l}\quad \text { ECOLOGY } \\
\text { - Terminology; } \\
\text { - Morphology; } \\
\text { - Syntax; } \\
\text { - Lingvopragmatic aspect; } \\
\text { - Historical aspect; } \\
\text { - Linguistic features }\end{array}$ & $\begin{array}{l}\quad \text { ECOLOGY } \\
\text { - Characteristics } \\
\text { of terminological } \\
\text { formation and } \\
\text { theme groups of } \\
\text { ecological lexicon; } \\
\text { - Ecological } \\
\text { lexicon in the } \\
\text { translation aspect } \\
\text { and cross-cultural } \\
\text { communication; } \\
\text { - the Ecological } \\
\text { discourse; } \\
\text { - Terminological } \\
\text { system of the } \\
\text { environment }\end{array}$ & - & - \\
\hline $\begin{array}{c}\text { POLITICS } \\
\text { - Types of professional texts }\end{array}$ & - & $\begin{array}{l}\text { POLITICS } \\
\text { - Professional } \\
\text { language as a } \\
\text { sociolect }\end{array}$ & - \\
\hline $\begin{array}{c}\text { ARCHITECTURE } \\
\text { - } \text { Communicative aspect; } \\
\text { - Types of professional texts }\end{array}$ & $\begin{array}{l}\text { ARCHITECTURE } \\
\text { - Terms at the level } \\
\text { of morphology, } \\
\text { semantics and } \\
\text { etymology }\end{array}$ & - & - \\
\hline $\begin{array}{l}\text { ADVERTISING } \\
\text { - Semantic and pragmatic } \\
\text { problems of advertizing texts; } \\
\text { - Problems of a text and its } \\
\text { communicative and economic } \\
\text { premises; } \\
\text { - Slogans due to classes; } \\
\text { - Semantic analysis of the } \\
\text { corpus of slogans; } \\
\text { - Advertisements in linguistic } \\
\text { and literary aspect }\end{array}$ & $\begin{array}{l}\text { ADVERTISING } \\
\text { - Lexical means } \\
\text { of a compression } \\
\text { in the English } \\
\text { advertizing texts; } \\
\text { - Language } \\
\text { features of } \\
\text { advertizing texts in } \\
\text { gender aspect; } \\
\text { - the } \\
\text { Lingvosemiotic } \\
\text { analysis of texts of } \\
\text { English-speaking } \\
\text { banner advertizing }\end{array}$ & - & - \\
\hline
\end{tabular}




\begin{tabular}{|c|c|c|c|}
\hline $\begin{array}{l}\text { ECONOMY } \\
\text { - Structural, semantic and } \\
\text { functional aspects of a term- } \\
\text { formation dynamics of the } \\
\text { German professinal language } \\
\text { of economy; } \\
\text { - Morphological and syntactic } \\
\text { features of functioning of } \\
\text { professional texts of economy }\end{array}$ & - & $\begin{array}{l}\quad \text { ECONOMY } \\
\text { - Terminological } \\
\text { aspect; } \\
\text { - The glottodidactic } \\
\text { aspect; } \\
\text { - Pragmatic } \\
\text { functioning } \\
\text { of terms- } \\
\text { phraseological } \\
\text { units in texts of } \\
\text { economy }\end{array}$ & - \\
\hline- & \begin{tabular}{|l}
\multicolumn{1}{|c}{ ASTRONOMY } \\
- The \\
terminological \\
phraseological \\
system of \\
English- speaking \\
professional texts
\end{tabular} & - & - \\
\hline- & \begin{tabular}{l}
\multicolumn{1}{c}{ SPORT } \\
- Word formation; \\
- Semantics; \\
- Syntax; \\
- Types of texts; \\
- The \\
sociolinguistic \\
research of football \\
language; \\
- Transmission \\
of an emotional \\
status of the \\
reporter or \\
commentator, \\
methods of \\
transmission of an \\
epistemological \\
modality and \\
verbal connection
\end{tabular} & \begin{tabular}{l}
\multicolumn{1}{c}{ SPORT } \\
- Metalexikographic \\
approach; \\
- Communicative \\
aspect
\end{tabular} & - \\
\hline- & $\begin{array}{c}\text { AIRCRAFT } \\
\text { - Functional and } \\
\text { semantic features }\end{array}$ & - & - \\
\hline- & $\begin{array}{l}\text { METALLURGY } \\
\text { - Terminological } \\
\text { aspect; } \\
\text { - Communicative } \\
\text { aspect; } \\
\text { - Semantic aspect }\end{array}$ & - & - \\
\hline- & $\begin{array}{l}\text { TECHNOLOGY } \\
\text { - Text structure }\end{array}$ & - & - \\
\hline- & $\begin{array}{l}\text { MINERALOLOGY } \\
\text { - Syntax }\end{array}$ & - & - \\
\hline
\end{tabular}




\begin{tabular}{|c|c|c|c|}
\hline- & $\begin{array}{l}\text { LINGUISTICS } \\
\text { - Word formation }\end{array}$ & - & - \\
\hline- & - & $\begin{array}{l}\quad \text { BUSINESS } \\
\text { - The glottodidactic } \\
\text { aspect; } \\
\text { - Types of } \\
\text { professional texts }\end{array}$ & - \\
\hline- & - & $\begin{array}{l}\quad \text { EXCHANGE } \\
\text { - Types of } \\
\text { professional texts }\end{array}$ & - \\
\hline- & - & $\begin{array}{c}\text { TOURISM } \\
\text { - Profesiolect of } \\
\text { tourism language }\end{array}$ & - \\
\hline- & - & - & $\begin{array}{l}\text { COSMETICS } \\
\text { - Terminological } \\
\text { aspect }\end{array}$ \\
\hline
\end{tabular}

Based on the results of the table it can be concluded that the common focus in the researches of the German and English languages has been given to syntax, terminology and semantics, however the difference has been found in the analysis centered on defining language peculiarities of the text through gender aspect, phrasal terms, sociological investigation of LSP, methods of conveying emotional status, epistemological modality and verbal connection. When in the German language the research has been focused mainly on linguistic parameters, and in the English language human centric aspect has been emphasized, then in the Polish language the main place has been taken by a glottodidactics (teaching), and as to the Ukrainian language, it has been on the initial stage of LSP development and only coins its terminology.

\section{HOW TO TEACH THE LANGUAGE FOR SPECIAL PURPOSES EFFECTIVELY (ON THE EXAMPLE OF THE LSP OF ECONOMICS, BUSINESS AND LAW)?}

Professional language of Business (Studies). The professional language of business studies has been considered by B. Ligara and W. Szupelak through glottodidactic aspect on the example of the Polish and English languages [5].

It was concluded that teaching terminology itself (teaching only term units) doesn't make a sense as it can be impossible to make up a sentence or a text. Summing up the results of the first part of the monograph B. Ligara emphasizes that teaching terminology of a foreign language should be based not only on onomasiological approach, but on texstological one as well [5].

B. Szupelak, while analyzing business language, takes into account two main criteria: 1) users of this professional language and 2) communicative situations. In case of users of business language, the subject outline of professional communication is dependent on the level of learners and their lingual and professional needs; therefore the author provides instructions which regard the participants' language competence. 
The main objective of the authors is how to teach a foreign language for business purpose effectively, in particular learning the Polish business language, and 5 scenarios of the lesson with exercises have been offered by them.

On analyzing collocations that occur near a term on sintagmatic axis, B. Ligara states that the choice of a collocation is not an issue of a professional language user's choice, but it is rather imposed by professional discourse. The author points out that the study of compatibility in specialized languages shows predominance of terms in syntagmas and specific combinations that are typical for a certain specialized language.

Professional language of Economics. The optimization of teaching and formation of a lexicon on the basis of economic language discourse (English economic language discourse) has been an issue of the analysis of K. Hryniuk [4]. The results of the research based on the English language of economics have been presented by the author in his work "Przyswajanie słownictwa fachowego dyskursu profesjonalnego na przykładzie tekstów biznesowych" [4]. K. Hryniuk shows the relations between pre-knowledge and factors which influence the receiving of a special lexicon which should be considered while translating.

O. Patseievska [6] considers peculiarities of pragmatic functioning of phraseological terms in the Polish texts of economics from the point of view of their contextual representation with regard to specifics of such texts in Polish economic discourse. The author points out that while teaching a professional language of economics one should take into account the fact that scientific economic texts are characterized by complexity and variety of syntactic structures, accuracy of statements, definitions, high terminological saturation including specialized terms and abstract lexical units; markers of such discourse, except terms, are units which specify the sequence and logic of presentation of thoughts, proofs and study techniques, typical or untypical characteristics, regularity of phenomena, origin, authorship, the way of expressing thoughts or concepts, level of information reliability [6].

Professional language of Law. In response to the urgent need of the study in the field, there is a research presented by Joanna Grzelak [3] on the Polish law language in glotodidactic perspective. The objective of the research is to define what should be concluded in the contents in order to train a foreigner for a participation in specialized legal communication. It should be mentioned here that glotodidaktics is not only a teaching technique. The main problem in teaching foreign languages is WHAT to teach. Only then it is possible to answer the question "HOW", using the relevant approaches and techniques. Before compiling a didactic program, a subject of study, in our case the Polish legal language, should be analyzed.

Main points:

- The formation of communicative competence in the sphere of legal communication differs from teaching general communication not only in the sense of selection of contents of study, but also the use of communicative skills;

- The communication in legal field is different in view of the nature of the law, its internal systematization, and that should be taken into account in glotodidactic process. Different branches of the law have created and used a 
different set of means which serve the communication. In the analytical part the author tries to investigate and to emphasize to what extent and in which aspects legal communication differs considering the field it is used.

The author confirms the thesis that formation of communicative competence in the sphere of the law should differ from the general communication in terms of communicative skills. In general communication, such kind of skills like speaking, listening, and interaction are of great importance, but within the analyzed specialized communication these are reading, writing and processing of information.

Legal communication is internally various in terms of the nature of law which is divided into different branches. Professional communication in civil, criminal and administrative law is elaborated by the sets of different genres and lexical resources. However, there are communicative elements that are common to all types of the law. It allows to compile the educational program in the form of modular system [3].

The linguistic analysis proves that legal communication is created due to legislative texts as its core component, and the main communicative activity comprises the provision of a legal act by a legislator and its decoding by an addressee / the recipient of the message. It is also confirmed by the genealogical analysis that indicates specific stylistic characteristics of legal acts in other fields of this type of communication, and also the analysis of lexicon which specifies that the basis of legislative lexicon consists of lexical units of legal acts.

\section{CONCLUSION}

Researches of LSP based on 4 languages (E G P U) differ in terms of approaches of scholars; in particular in the Polish language we can see a different linguistic pattern comparing with the German and English languages. The research in the German language has been focused mainly on the linguistic analysis, in the English language it has dealt with anthropocentric aspect, and then in the Polish language the main stress has been put on a glottodidactics (teaching). The issues related to teaching professional languages are connected with the processes of teaching and leaning specialized languages. Hence, teaching the translation skills of professional texts is a specific option of didactics of LSP that undergoes constant difficulties and requires the formation of optimum tools for their overcoming.

\section{References}

1. Grucza, Sambor (2008). Zur Geschichte der Fachtextlinguistik. In: Studia Germanica Posnaniensia XXXI. 11-23.

2. Grucza, Sambor (2002). Badania nad językami specjalistycznymi w Niemczech, [w:] «Języki specjalistyczne», t. 2, Problemy technolingwistyki, J. Lewandowski (red.), KJS, Warszawa, 81-100.

3. Grzelak-Piaskowska, Joanna. (2010). Polski język prawa w perspektywie glottodydaktycznej. praca doktorska: Poznan.

4. Hryniuk, Katarzyna. (2009). Przyswajanie słownictwa fachowego z dyskursu profesjonalnego na przykładzie tekstów biznesowych. In: A. Waszczuk-Zin (Hrsg.), W kręgu problematyki technolektalnej. Band 2. Warszawa. 96-115.

5. Ligara Bronislawa, Szupelak Wojciech. (2012). Lingwistyka i glottodydaktyka języków spec- 
jalistycznych na przykładzie języka biznesu. Podejście porównawcze. Księgarnia Akademicka, Kraków, 273.

6. Patseievska, Olena. (2011). Prahmatychnyi efekt kontekstualnoho otochennia termina u polskykh ekonomichnykh tekstakh. Komparatyvni doslidzhennia slov'ianskykh mov i literatur. Pam'iati akademika Leonida Bulakhovskoho. - Vyp. 15, 196-205.

7. Vorobeva, Svetlana. (2010). Lingvosemioticheskaya spetsifika angloyazyichnogo srednevekovogo gastronomicheskogo diskursa. Vestnik Nizhegorodskogo gosudarstvennogo lingvisticheskogo universiteta im. N.A. Dobrolyubova. - №12. - Nizhniy Novgorod : Izd-vo GOU VPO NGLU, 32-43.

Стаття надійшла до редакції 16.09.2017 p. 